\title{
Life cycle assessment of zircon sand
}

\section{Johannes Gediga ${ }^{1}$ (D) $\cdot$ Andrea Morfino ${ }^{1} \cdot$ Matthias Finkbeiner $^{2} \cdot$ Matthias Schulz $^{3} \cdot$ Keven Harlow $^{4}$}

Received: 24 June 2018 / Accepted: 27 March 2019 /Published online: 17 May 2019

(C) The Author(s) 2019

\begin{abstract}
Purpose To support the needs of downstream users of zircon sand and other industry stakeholders, the Zircon Industry Association (ZIA) conducted an industry-wide life cycle assessment (LCA) with the aim to quantify the potential environmental impacts of zircon sand production, from mining to the separation of zircon sand (zirconium silicate or $\mathrm{ZrSiO}_{4}$ ). This novel work presents the first, globally representative LCA dataset using primary data from industry. The study conforms to relevant ISO standards and is backed up by an independent critical review.

Methods Data from ZIA member companies representing 10 sites for the reference year 2015 were collected. In total, more than $77 \%$ of global zircon sand production was covered in this study. All relevant mining routes (i.e. wet and dry mining) were considered in the investigation, as well as all major concentration and separation plants in major zircon sand-producing regions of the world (i.e. Australia, South Africa, Kenya, Senegal and the USA). As it is common practise in the metal and mining industry, mass allocations were applied with regard to by-products (Santero and Hendry, Int J Life Cycle Assess 21:1543-1553, Santero and Hendry 2016) where economic allocation is only applied if high-valued metals like PGMs are separated with a process flow. A sensitivity analysis was used to understand the relevance of the major contributing effect of the life cycle impact assessment (LCIA) results, power consumption.

Results and discussion It was shown that mining is the main contributor to all impact categories (between 65 and $90 \%$ compared with the mineral separation plant). For example, primary energy demand (PED) and global warming potential (GWP) contribute $76 \%$ and $70 \%$, respectively, to the production of $1 \mathrm{~kg}$ of zircon sand. PED for $1 \mathrm{~kg}$ of zircon sand is calculated to be $4 \mathrm{MJ}$, whereas the GWP is $0.32 \mathrm{~kg} \mathrm{CO}_{2}$ equivalent per $\mathrm{kg}$ of zircon sand. The main influencing factor in the mining process is electricity consumption.

Conclusions In conformity with relevant ISO standards, and backed up by a critical review, this LCA quantified the potential environmental impacts associated with the production of the zircon sand $\left(\mathrm{ZrSiO}_{4}\right)$. With this study, a sound dataset for downstream users of zircon sand has been provided. It is the first LCA dataset of the ZIA.
\end{abstract}

Keywords Ceramics $\cdot$ LCA $\cdot$ Cradle-to-gate $\cdot$ Global average $\cdot$ Global warming potential $\cdot$ Ilmenite $\cdot$ Life cycle impact assessment $\cdot$ Rutile $\cdot$ Sand $\cdot$ Zircon

Responsible editor: Yi Yang

Johannes Gediga

johannes.gediga@thinkstep.com

1 thinkstep AG, Hauptstraße 111-113, 70771 Leinfelden-Echterdingen, Germany

2 Chair of Sustainable Engineering, Technische Universität Berlin, Strasse des 17. Juni 135, 10623 Berlin, Germany

3 Schulz Sustainability Consulting, Baldernstr. 2, 70469 Stuttgart, Germany

4 Zircon Industry Association, Grenville Court, Burnham, Bucks SL1 8DF, UK

\section{Introduction}

In view of the ongoing societal debate on energy efficiency and climate change, life cycle assessment (LCA) data for products and processes play an increasingly important role in material selection and product development (e.g. Finkbeiner et al. 2006). Material selection can be influenced by objective sustainability measures (e.g. "carbon footprint") as well as the material's technical characteristics.

Zircon sand is applied as is or transformed to many industrial applications, like ceramics, precision casting, refractories, catalysts, fuel cells, fibre optics, nuclear power generation, water treatment and medical prosthetics. The tile market is the biggest market for the zircon sand industry (utilising over 
$50 \%$ of zircon sand production). Since the building and construction sector is using LCA as a part for building certification, it is essential to have reliable LCA data available.

Zircon sand is one of the two core product streams from "mineral sand," the other being titanium minerals (ilmenite, leucoxene and rutile). Zircon is a zirconium silicate, with the chemical formula $\mathrm{ZrSiO}_{4}$ and structure represented in Fig. 1. This mineral substance is a very hard, highly refractive, birefringent refractory material. Zircon may contain traces of uranium and thorium (up to $1 \%$ ) in the crystal structure, along with hafnium which is not considered a by-product in this study since no data were available, and is therefore considered a NORM (naturally occurring radioactive material) (World Nuclear Association 2014). Zircon is traded in sand or milled powder forms; the specifications for which vary depending on the application (e.g. as an opacifier in ceramic tiles, zircon sand is milled to a fine powder).

Deposits of mineral sands are formed along ancient coastlines where the heavier minerals were concentrated by wave and wind action over millions of years. Most mineral sand deposits are found in unconsolidated fossil shorelines several hundred metres to tens of kilometres - or occasionally hundreds of kilometres - inland from the present coastline. Major deposits are found not only in Australia and South Africa but also in South and Southeast Asia, China, East and West Africa, Ukraine and North and South America.

The heavy mineral content of these deposits can range from 0.5 to $>20 \%$. Similarly, the zircon content varies from deposit to deposit, ranging from 1 to as high as $50 \%$.

Mining Zircon sand is mined in two ways: dry mining (the above-described inland deposits) and wet mining (using dredges) along the coastlines (ZIA 2015). Dry mining is the most commonly used method that can be applied to hard ground deposits, discontinuous deposits and small tonnage high-grade deposits. Traditional earthmoving equipment (employing scrapers, dozers and excavators) is used to excavate and transport the sand to the processing plants.

Wet mining typically involves using a floating dredge and concentrator in an enclosed pond, with the concentrator moving along behind the dredge within the pond. Alternatively, high-pressure water hoses can be used to break down sand dunes containing the mineral deposit.

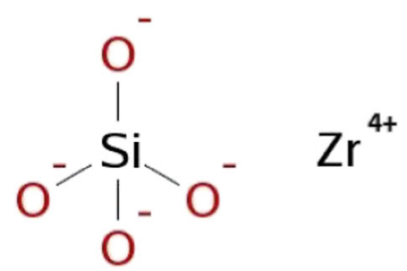

Fig. 1 Typical chemical structure of zircon (Zircon Industry Association 2015)
Processing The processing method used to produce a heavy mineral concentrate (HMC) from the mined sand varies depending on the deposit's specific mineral configuration. Extracting heavy minerals from the feedstock is commonly achieved by wet gravity separation techniques (e.g. spirals), but bulk froth flotation processing of gangue minerals is used at some hard rock operations.

During dredging, wet concentration is carried out in the floating concentrator; whereas in dry mining, feed preparation or mining unit plants (MUP) are mobile, to minimise the distance the sand is transported. A slurry produced at the MUP is then pumped to the concentrator. In both wet and dry mining, the tailings are pumped from the concentrator to backfill the mined areas.

Wet separation typically produces $90-96 \%$ heavy minerals (HM) in the HMC that is moved to a mineral separation plant (or dry plant). In many instances, the HM undergo scrubbing to clean the surfaces of the mineral grains. Once scrubbed, the $\mathrm{HM}$ are dried and separated via magnetic, electrostatic and gravity separation.

The results from the study are presented in this article, focusing on a selection of key energy resources, emissions and impact categories. The complete inventory is available in the $\mathrm{GaBi}$ database format and can be requested from the Zircon Industry Association (ZIA).

Because of the fact that heavy mineral sands belong to the group of NORM, it was the intention to include related potential environmental effects in this study. Due to the fact that little data was available for quantifying natural ionising radiation during the production phase of zircon sand, a sensitivity analysis was done during the use phase comparing respective effects with other building materials used in the construction sector. The NORM issue during the production of zircon sand will be a topic for future research. Besides collecting reliable data, also how to integrate and assess the natural occurring radioactivity in LCA will need investigation and research activity.

\section{Methodology}

\subsection{Goal and scope}

The aim of this study was to identify the process steps with the highest contribution to the potential environmental impacts of zircon sand production and to develop a representative LCA dataset using current, robust data on zircon sand production from 2015 that is representative for the global production mix. The study represents more than $77 \%$ of world zircon sand production covering 10 production sites of eight member companies of the ZIA.

This novel study was conducted in accordance with existing standards (ISO 14040: 2006 and ISO 14044: 2006). 
The study was reviewed by a critical review panel in accordance with ISO 14071 (2014).

Functional unit The focus of the study was to produce a global average of zircon sand; therefore, the following functional unit was chosen: $1 \mathrm{~kg}$ of zircon sand $\left(\mathrm{ZrSiO}_{4}\right)$.

For zircon sand production, the primary production (from the mine to the gate of the mineral separation plant) was only considered, and end-of-life recovery was not considered.

\subsection{System boundary}

The study is a "cradle-to-gate" LCA study covering all process steps from mineral sand extraction (i.e. the cradle) to the finished zircon sand ready to be transported from the production plant (i.e. the gate). This choice of system boundaries is in line with the scope and goal of the study.

The system boundary includes all production processes of the eight participating companies, for both dry and wet mining as well as the mineral separation plants (MSPs) of all participating companies. The system boundary is illustrated in Fig. 2.

\subsection{Geographical and technological representation}

The geographical scope of the study is global. Eight companies with, in total, 10 sites contributed to the study. All major heavy mineral sand-producing regions were covered, including the following countries:

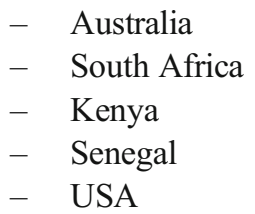

Since this is an industry study, using primary industry data, no effort was made to create theoretical inventory data and impacts to represent missing producers in different regions of the world. The primary data are actual zircon sand production data for the year 2015. The upstream data was taken from commercially available GaBi 2017 SP34 database and is mainly representative for the years 2014 and 2016 (electricity and fuels as well as materials).

The technology covered in the study includes wet and dry mining and the typical MSPs for the different regions of the world. Wet mining covers 418,200 tonnes of heavy mineral sand and dry mining comprises 639,100 tonnes of heavy mineral sand (TZMI 2016).

\subsection{Treatment of by-products}

Zircon sand mining typically yields several other mineral products such as ilmenite, rutile and leucoxene. These
Fig. 2 System boundary considered in the production of zircon sand

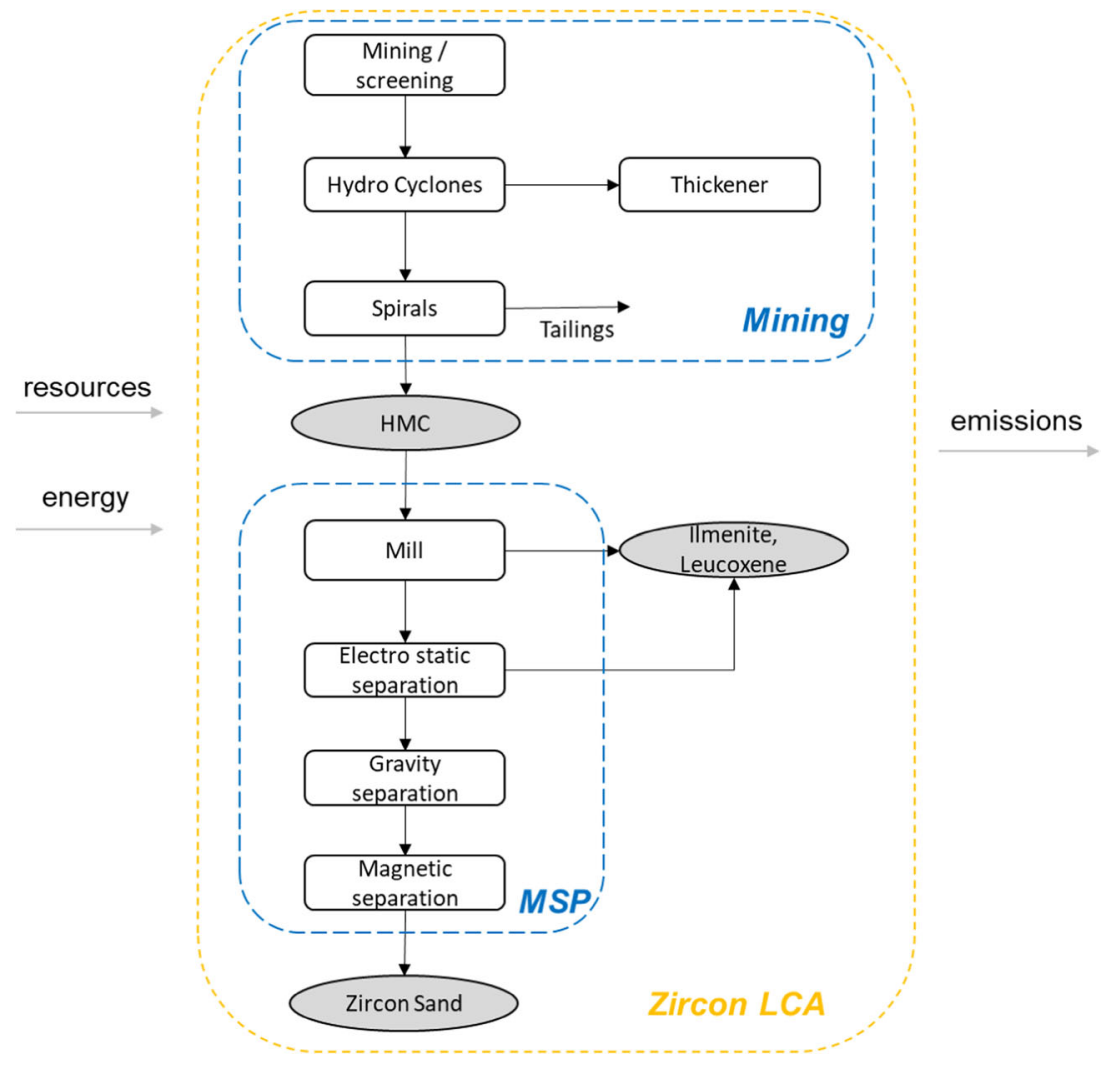


minerals are not included within the scope of this study and are, therefore, treated as by-products.

In accordance with the "Harmonization of LCA methodologies for the metal and mining industry" paper (Santero and Hendry 2016) as well as following the existing LCA dataset of titanium dioxide (for which mass allocation was applied between rutile, ilmenite, leucoxene and zircon), mass allocation was also chosen for this current study. Having different allocation methods applied for minerals coming from one ore composition is not in line with ISO standards, and therefore, no sensitivity analysis was carried out for different allocation methods.

\subsection{Data sources, data quality, data gaps and result calculation}

\subsubsection{Data collection and quality}

Questionnaires for data collection were developed according to heavy mineral industry standards and revised together with participating companies. Data were collected using industry-specific spreadsheets. The questionnaires addressed the unit process data for the respective zircon sand production (wet or dry mining, beneficiation and MSP) including any on-site utilities. After receiving the questionnaires, the authors cross-checked for completeness and plausibility using mass balance, stoichiometry (check by calculation of $\mathrm{CO}_{2}$ based on carbon input) and internal and external benchmarking of the respective processes. Where data gaps or other inconsistencies occurred, the authors engaged with the respective company to resolve any open issues.

No cut-off criteria were used in collecting data as it was intended to capture the complete material and energy inputs as well as waste and emission output. Those data were reviewed by an internal data quality check to eliminate data gaps and data reporting errors. The average unit process data over the 10 sites assessed are shown below in Sect. 3 .

\subsubsection{Foreground system}

This study was based on primary data collected from member companies and their respective production sites (so-called foreground system) representing round $77 \%$.

The structure of the foreground model is similar for all participating companies, but the upstream datasets are specific according to the country where the mines and MSPs are located.

The main input-output flows per unit process can be seen in Table 2 below where the average unit processes are displayed.

\subsubsection{Background system, software and database}

The LCA model was created using the GaBi Software system for life cycle engineering, developed by thinkstep AG. The $\mathrm{GaBi}$ database provides the life cycle inventory (LCI) data for the fuels and energy as well as raw and process materials obtained from the upstream system (thinkstep 2017). Upstream data for fuel production and electricity generation were taken from IEA (2016) and, if available, from sitespecific power providers or on-site power generation (e.g. diesel generators). Examples of process materials include limestone, sulphuric acid and sodium hydroxide. Regional upstream data were applied where available. In cases where country-specific datasets for some regions were not available, proxy datasets were used. $\mathrm{GaBi}$ datasets were developed following ISO 14040/14044 standards and are compliant with ELCD methodology.

Emission data associated with the production processes of zircon sand were derived from the collection of primary data and by consultation with primary contacts at the participating companies familiar with the specific operations. It was found that most of the iterative steps were necessary in order to achieve a representative emission profile of the direct emissions associated with zircon sand production.

\subsubsection{Data aggregation and averaging}

The LCI profile was calculated for each company/plant; the resulting values were averaged across the contributing sites based on production tonnages-weighted vertical aggregation.

The LCI was calculated for each company, and their production sites - involving the processes of the given technology with its given yields - and the resulting LCIs were averaged across several production sites. The horizontal averaging approach was used at a process level for benchmarking during the data quality check. The data quality check compared, for example, all wet and dry mines as well as all MSP processes separately.

\subsection{Selection of the life cycle impact assessment method}

The life cycle impact assessment (LCIA) links the usage of resource and emission data from the LCI to potential impacts on the environment. LCIA methodologies can differ in different regions in the world (e.g. in the USA, the TRACI method (Bare 2002) is often applied; in Japan, the LIME method (Itsubo N Inaba 2012)). In the European context, LCIA methods include Centre of Environmental Science at Leiden (CML) (Guinée et al. 2002), ReCiPe (Goedkoop et al. 2009) and selected methods recommended by the International Reference Life Cycle Data System (ILCD) (ILCD 2011). 
The LCIA of this study is based on the CML impact assessment methodology. CML characterisation factors that are applicable to the European context are widely used and respected within the LCA community (Bach and Finkbeiner 2017) and are required for Environmental Product Declarations under EN 15804 (CEN 2013) for the construction and building sector (noting that over $50 \%$ of zircon sand is used in the ceramic tile sector). Therefore, the impact categories applied in this study are based on CML 2001 (January 2016) characterisation factors.

A list of CML indicators selected for this study is shown in Table 1. CML characterisation factors are applicable to the European context, are widely used and are respected within the LCA community. CML is required for Environmental Product Declarations under EN 15804 (CEN 2013) for the construction and building sector where over $50 \%$ of the produced zircon sand is used.

With regard to the water consumption indicator which was considered as well, a water scarcity assessment would have been possible and would give even a better insight about the potential impact of water usage. However, this was not the focus of the current study. Future updates may address the impacts of water consumption related to the different mining regions and the related water sheds (Northey et al. 2018). Additionally, there is no method for the regional impact of the radiation available which needs more research.

\section{Results and discussion}

In the following, the average unit processes for mining and MSP are shown (Table 2).

\subsection{Life cycle inventory}

The LCI results for the cradle-to-gate production of zircon sand are shown in Table 3. The results shown here are a key selection of inventory data which are most common in the LCA community as well as closely related to the production technologies under research. The complete cradle-to-gate inventory can be found in the GaBi 8 database (2017) and is available upon request from the Zircon Industry Association (ZIA) as a cradleto-gate process.

\subsection{Life cycle impact assessment}

An overview of the LCIA results using the CML methodology is shown in Table 4.

\subsection{Interpretation}

Figure 3 describes the contributions for different stages and processes connected with the total production of zircon sand, resulting from the weighted average of all mining sites in this study. It considers the mining/beneficiation process and the MSP process.

The principal contributing factor to the different impact categories (except for abiotic depletion elements (ADPe)) is the conversion from fuels to electricity (called energy conversion in Fig. 3). Comparing with Fig. 4, it is apparent that the mining process is the major driver of the potential impacts due to the use of dredging devices and other machining equipment to mine the mineral sand.

ADPe is driven by auxiliary materials' consumption, mainly tyres and batteries, with high consumption of elementary resources and elements like lead $(82 \%)$, silver $(12 \%)$ and zinc $(4 \%)$. End-of-life (EoL) credits relate to the disposal and recovery processes of these auxiliary materials consumed and therefore landfilled mainly during mining operations. The so-called "combustion process" in Fig. 3 comprises the combustion of fuels used for onsite power generation (e.g. diesel generators at remote sites), haulage trucks and necessary thermal energy within the MSP. The combustion processes have a main influence on eutrophication, summer smog (POCP), acidification (AP) and global warming (GWP).
Table 1 CML 2001 impact category descriptions

\begin{tabular}{lll}
\hline Impact category & Impact category indicator & Source \\
\hline Global warming potential (GWP) & $\mathrm{kg} \mathrm{CO}_{2}$ equivalent & (IPCC 2013) \\
Ozone layer depletion potential (ODP) & $\mathrm{kg} \mathrm{CFC-11} \mathrm{equivalent}$ & (WMO 2003) \\
Photochemical ozone creation potential (POCP) & $\mathrm{kg}$ ethylene equivalent & (Jenkin and Haymen 1999) \\
& & (Derwent et al. 1998) \\
Acidification potential (AP) & $\mathrm{kg} \mathrm{SO}_{2}$ equivalent & (Huijbregts 1999) \\
Eutrophication potential (EP) & $\mathrm{kg} \mathrm{PO}_{4}--$ - equivalent & (Heijungs et al. 1992) \\
Abiotic depletion elements (ADPe) & $\mathrm{kg} \mathrm{Sb}$ equivalents & (Van Oers et al. 2002) \\
Abiotic depletion fossil (ADPf) & $\mathrm{MJ}$ & (Van Oers et al. 2002) \\
\hline
\end{tabular}


Table 2 Average unit process of heavy mineral sand mining and MSP

Mining

Input

Electric power

Diesel consumption

Ore mined

Ground water

Lake water

Rain water

Sea water

Waste water

Aluminium sulphate

Sodium hydroxide (100\%; caustic soda)

Lubricating oil

Output

HMC (heavy mineral concentrate)

Tailings (deposited)

Water loss (e.g. evaporation and seepage)

Water released to environment

Waste for recovery

Non-hazardous waste for landfilling

Used oil

MSP

Input

Electricity

Natural gas

Diesel

HMC concentrate

Sulphuric acid (96\%)

Ground water

Lake water

Waste water (in)

Tap water

Lubricating oil

Output

$\begin{array}{lll}\text { Ilmenite } & \mathrm{kg} & 4.59 \mathrm{E}-01 \\ \text { Rutile } & \mathrm{kg} & 1.46 \mathrm{E}-01 \\ \text { Zirconium } & \mathrm{kg} & 3.57 \mathrm{E}-01 \\ \text { Tailings (deposited) } & \mathrm{kg} & 3.91 \mathrm{E}-01 \\ \text { Non-hazardous waste for landfilling } & \mathrm{kg} & 2.84 \mathrm{E}-02 \\ \text { Water loss (e.g. evaporation and seepage) } & \mathrm{kg} & 9.60 \mathrm{E}+00 \\ \text { Waste water } & \mathrm{kg} & 3.24 \mathrm{E}+00 \\ \text { Used oil } & \mathrm{kg} & 7.20 \mathrm{E}-04 \\ \text { Emission to air } & & \\ \text { Titanium } & \mathrm{kg} & 1.91 \mathrm{E}-06 \\ \text { Zircon } & \mathrm{kg} & 3.87 \mathrm{E}-06 \\ \text { Dust (PM2.5-PM10) } & \mathrm{kg} & 9.51 \mathrm{E}-05 \\ \text { Emission to water } & & \\ \text { Titanium } & \mathrm{kg} & 5.91 \mathrm{E}-08 \\ & & \end{array}$

The italicized data are the main mass flow material in and material out. HMC concentrate out of the mining. HMC concentrate into MSP and three products out
Table 3 Cradle-to-gate LCI results per kg zircon sand

\begin{tabular}{|c|c|c|}
\hline Type & Flow & Amount \\
\hline \multirow[t]{7}{*}{ Resources } & Ore mined & $3.7 \mathrm{E}+01$ \\
\hline & Water & $6.6 \mathrm{E}+01$ \\
\hline & Crude oil & $2.5 \mathrm{E}-02$ \\
\hline & Hard coal & $6.9 \mathrm{E}-02$ \\
\hline & Natural gas & $1.6 \mathrm{E}-02$ \\
\hline & Uranium & $1.8 \mathrm{E}-07$ \\
\hline & Lignite & $1.5 \mathrm{E}-02$ \\
\hline \multirow[t]{11}{*}{ Emissions to air } & $\mathrm{CO}_{2}$ & $2.9 \mathrm{E}-01$ \\
\hline & $\mathrm{CH}_{4}$ & $7.2 \mathrm{E}-04$ \\
\hline & $\mathrm{N}_{2} \mathrm{O}$ & $4.0 \mathrm{E}-06$ \\
\hline & $\mathrm{NO}_{x}$ & $1.7 \mathrm{E}-03$ \\
\hline & $\mathrm{SO}_{2}$ & $1.3 \mathrm{E}-03$ \\
\hline & NMVOC & $1.1 \mathrm{E}-04$ \\
\hline & $\mathrm{CO}$ & $3.9 \mathrm{E}-04$ \\
\hline & PM10 & $3.7 \mathrm{E}-05$ \\
\hline & PM2.5-PM10 & $7.9 \mathrm{E}-05$ \\
\hline & PM2.5 & $8.1 \mathrm{E}-05$ \\
\hline & Heavy metals & $9.0 \mathrm{E}-06$ \\
\hline \multirow[t]{4}{*}{ Emissions to water } & $\mathrm{Cl}^{-}$ & $2.1 \mathrm{E}-03$ \\
\hline & NH3 & $6.85 \mathrm{E}-08$ \\
\hline & $\mathrm{PO}_{4}^{3-}$ & $7.83 \mathrm{E}-07$ \\
\hline & Heavy metals & $3.40 \mathrm{E}-05$ \\
\hline
\end{tabular}

Transport of the HMC to the MSP and transport of final zircon sand to the port of shipment have only a minor contribution $(<6 \%)$ to the potential environmental impacts.

Table 4 Cradle-to-gate global average LCIA results per $\mathrm{kg}$ of zircon sand (CML 2001 indicators)

\begin{tabular}{ll}
\hline Environmental indicator (per kg of zircon sand) & Value \\
\hline $\mathrm{ADPe}(\mathrm{kg} \mathrm{Sb}$ eq.) & $1.1 \mathrm{E}-07$ \\
$\mathrm{ADPf}(\mathrm{MJ})$ & $3.8 \mathrm{E}+00$ \\
$\mathrm{AP}\left(\mathrm{kg} \mathrm{SO}{ }_{2}\right.$ eq.) & $2.6 \mathrm{E}-03$ \\
$\mathrm{EP}(\mathrm{kg}$ phosphate eq.) & $2.4 \mathrm{E}-04$ \\
$\mathrm{GWP}\left(\mathrm{kg} \mathrm{CO}{ }_{2}\right.$ eq.) & $3.2 \mathrm{E}-01$ \\
$\mathrm{ODP}(\mathrm{kg} \mathrm{R} 11$ eq.) & $6.8 \mathrm{E}-12$ \\
POCP (kg ethylene eq.) & $1.5 \mathrm{E}-04$ \\
PED (MJ) & $4.0 \mathrm{E}+00$ \\
Water consumption (kg) & $2.0 \mathrm{E}+01$ \\
\hline
\end{tabular}


Fig. 3 Potential impacts contributing to the production of $1 \mathrm{~kg}$ of zircon sand

Fig. 4 Relative contribution of mining and MSP
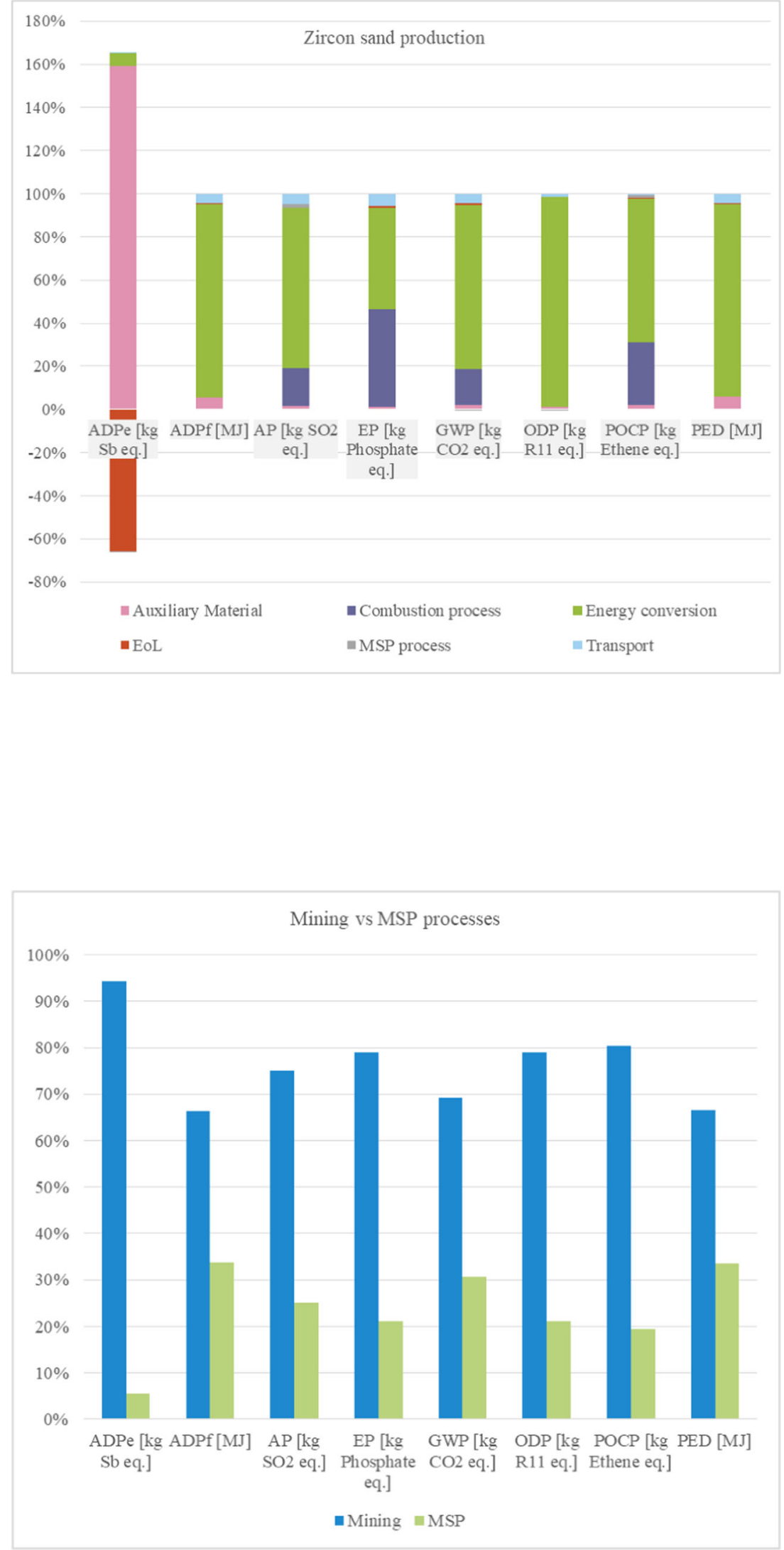
Table 5 Sensitivity analysis for electricity consumption for mining and MSP

\begin{tabular}{lcccc}
\hline Percentage variation & $-10 \%$ & $+10 \%$ & $-30 \%$ & $+30 \%$ \\
\hline & \multicolumn{4}{c}{ Electricity consumption (mining) } \\
AP & $<6 \%$ & $>6 \%$ & $<19 \%$ & $>18 \%$ \\
EP & $<5 \%$ & $>4 \%$ & $<13 \%$ & $>12 \%$ \\
GWP & $<6 \%$ & $>5 \%$ & $<16 \%$ & $>16 \%$ \\
ODP & $<8 \%$ & $>7 \%$ & $<24 \%$ & $>23 \%$ \\
& & Electricity consumption (MSP) \\
AP & $<2 \%$ & $>2 \%$ & $<5 \%$ & $>5 \%$ \\
EP & $<1 \%$ & $>1 \%$ & $<3 \%$ & $>3 \%$ \\
GWP & $<2 \%$ & $>2 \%$ & $<5 \%$ & $>5 \%$ \\
ODP & $<2 \%$ & $>2 \%$ & $<6 \%$ & $>6 \%$ \\
\hline
\end{tabular}

\subsection{Sensitivity analysis}

Sensitivity analysis was used to evaluate how the results change when values for the most contributing process were altered. The main contributing factor in this study was the energy conversion, respectively, the energy consumption. Based on this, it was determined how the results would change if the power consumption is varied by $+/-30 \%$ (a value that represents the real variability of the electricity consumption considering the same kind of mining (wet or dry) and MSP and the same country production).

In Table 5, the relative changes of the LCIA results of $1 \mathrm{~kg}$ of zircon sand for the selected categories are shown. The power consumption for the mining and for the MSP was varied separately per process.

\section{Conclusions}

This novel LCA study provides the first, globally representative environmental inventory and impact assessment profile for zircon sand production based on primary data. ZIA members provided high-quality life cycle assessment data covering zircon sand production from the mine to the MSP gate, with high geographical coverage (77\% of the world production) and technological representativeness (all important processes, wet and dry mining, beneficiation and MSP, are covered in the data). The results show that the environmental profile of zircon sand production is mainly driven by energy-related processes, particularly during mining and heavy mineral concentration. As a consequence, the country-specific electricity mixes have a strong influence on the results as seen in Fig. 3 in green. The majority of other environmental issues are due to generation of thermal energy or combustion of fuel, both for drying processes and raw materials' haulage as can be seen in Fig. 3 in dark blue and light blue. The impact of tailing dams was not considered in this study since no tailing dam simulation was available for the study. This might in general be a very important issue for LCA dataset having mining operations especially the impact of acid drainage and the impact of metals into soil, groundwater, etc. On this topic, a major research needs to be done.

Acknowledgements The authors acknowledge with thanks the following ZIA member companies for their participation in this study and for the provision of production data: Base Titanium Ltd., Iluka Resource Ltd., MZI Resources Ltd., Rio Tinto Ltd., Sibelco, TiZir Ltd., Southern Ionic Minerals and Tronox Ltd.

Open Access This article is distributed under the terms of the Creative Commons Attribution 4.0 International License (http:// creativecommons.org/licenses/by/4.0/), which permits unrestricted use, distribution, and reproduction in any medium, provided you give appropriate credit to the original author(s) and the source, provide a link to the Creative Commons license, and indicate if changes were made.

\section{References}

Bach V, Finkbeiner M (2017) Approach to qualify decision support maturity of new versus established impact assessment methodsdemonstrated for the categories acidification and eutrophication. Int J Life Cycle Assess 22:387-397

Bare J (2002) Developing a consistent decision-making framework by using the U.S. EPA's TRACI

CEN (2013) EN 15804, sustainability of construction works - environmental product declarations - core rules for the product category of construction. EUROPEAN COMMITTEE FOR STANDARDIZATION

Derwent RG, Jenkin ME, Saunders SM, Pilling MJ (1998) Photochemical ozone creation potentials for organic compounds in Northwest Europe calculated with a master chemical mechanism. Atmos Environ 32:2429-2441

Finkbeiner M, Hoffmann R, Ruhland K, Liebhart D, Stark B (2006) Application of life cycle assessment for the environmental certificate of the Mercedes-Benz S-class. Int J Life Cycle Assess 11(4):240 246

GABI MODELLING PRINCIPLES (2017) edition, January 2017: http:// www.gabisoftware.com/fileadmin/GaBi_Databases/ GaBi Modelling Principles 2017.pdf

Goedkoop M, Heijungs R, Huijbregts M (2009) ReCiPe 2008 a life cycle impact assessment method which comprises harmonised category indicators at the midpoint and the endpoint level report I: characterisation. Ruimte Enmilieu, Ministerie Van Volkshuisvesting, Tuimtelijke Ordening en Milieubeheer

Guinée JB, Gorrée M, Heijungs R, Huppes G, Kleijn R, de Koning A, van Oers L et al (2002) Handbook on life cycle assessment. Operational guide to the ISO standards. Kluwer, Dordrecht

Heijungs R, Guinée J, Huppes G, Lankreijer RM, Udo de Haes HA, Wegener Sleeswijk A, Ansems AMM, Eggels PG, van Duin R, de Goede HP (1992) Environmental life cycle assessment of products. Guide and backgrounds. Centre of Environmental Science (CML), Leiden University, Leiden

Huijbregts M (1999) Life cycle impact assessment of acidifying and eutrophying air pollutants. Calculation of equivalency factors with RAINS-LCA. Interfaculty Department of Environmental Science, Faculty of Environmental Science, University of Amsterdam 
ILCD (2011) European Commission-Joint Research Centre - Institute for Environment and Sustainability: international reference life cycle data system (ILCD) handbook- recommendations for life cycle impact assessment in the European context, first edition, November 2011, EUR 24571 EN, Luxemburg, Publications Office the European Union; 2011

International Energy Agency World Energy Statistics; Data services 2016 edition, Paris, France

IPCC (2013) Climate change 2013: the physical science basis. IPCC, Geneva, Switzerland

ISO 14040 (2006) Environmental management - life cycle assessment principles and framework. International Organization for Standardization, Geneva

ISO 14044 (2006) Environmental management - life cycle assessment requirements and guidelines. International Organization for Standardization, Geneva

ISO 14071 (2014) Environmental management - life cycle assessment critical review processes and reviewer competencies: additional requirements and guidelines to ISO 14044:2006. International Organization for Standardization, Geneva

Itsubo N Inaba A (2012) LIME 2-life-cycle impact assessment method based on endpoint modeling - summary

Jenkin ME, Haymen GD (1999) Photochemical ozone creation potentials for oxygenated volatile organic compounds: sensitivity to variations in kinetic and mechanistic parameters. Atmos Environ 33:1275-1293
Northey AS, Madrid López C, Haque N, Mudd G, Yellishetty M (2018) Production weighted water use impact characterisation factors for the global mining industry. J Clean Prod 184:788-797

Santero N, Hendry J (2016) Harmonization of LCA methodologies for the metal and mining. Int J Life Cycle Assess 21:1543-1553

thinkstep (2017) GaBi LCA database documentation. http://databasedocumentation.gabi-software.com

TZMI (TZ Minerals International) 2016

Van Oers L, de Koning A, Guinée JB, Huppes G (2002) Abiotic resource depletion in LCA. Ministry of Transport, Public Works and Water Management, The Hague

WMO (2003) Scientific assessment of ozone depletion: global ozone research and monitoring. Organisation, World Meteorological

World Nuclear Association (WNA) (2014) Naturally-occurring radioactive material, Appendix 1

Zircon Industry Association (2015) Technical handbook on zirconium and zirconium compounds. Zircon Industry Association

Publisher's note Springer Nature remains neutral with regard to jurisdictional claims in published maps and institutional affiliations. 